\title{
Stage IIA Gallbladder Cancer AJCC v8
}

National Cancer Institute

\section{Source}

National Cancer Institute. Stage IIA Gallbladder Cancer A/CC v8. NCI Thesaurus. Code C134670.

Stage IIA includes: T2a, N0, M0. T2a: Tumor invading the perimuscular connective tissue on the peritoneal side, without involvement of the serosa (visceral peritoneum). N0: No regional lymph node metastasis. M0: No distant metastasis. (AJCC 8th ed.) 